\title{
First identification of natural infection of Rickettsia rickettsii in the Rhipicephalus sanguineus tick, in the State of Rio de Janeiro ${ }^{1}$
}

\author{
Nathalie C. Cunha ${ }^{2}$, Adivaldo H. Fonseca ${ }^{*}$, Jania Rezende ${ }^{2}$, Tatiana \\ Rozental $^{4}$, Alexsandra R.M. Favacho ${ }^{4}$, Jairo D. Barreira ${ }^{4}$, Carlos L. Massard ${ }^{5}$ \\ and Elba R.S. Lemos ${ }^{4}$
}

\begin{abstract}
Cunha N.C., Fonseca A.H., Rezende J., Rozental T., Favacho A.R.M., Barreira J.D., Massard C.L., Lemos E.R.S. 2009. First identification of natural infection of Rickettsia rickettsii in the Rhipicephalus sanguineus tick, in the State of Rio de Janeiro. Pesquisa Veterinária Brasileira 29(2):105-108. Curso de Pós-Graduação em Ciências Veterinárias, Universidade Federal Rural do Rio de Janeiro, Seropédica, RJ 23890-000, Brazil. E-mail: adivaldo@ ufrrj.br

The Brazilian Spotted Fever (BSF) is a zoonotic disease caused by Rickettsia rickettsii and transmitted by ticks of the genus Amblyomma, more frequently, Amblyomma cajennense. The aim of this paper was to report the first molecular detection of $R$. rickettsii on $R$. sanguineus naturally infected in Rio de Janeiro, Brazil. Ticks were collected from dogs in a rural region of Resende municipality, Rio de Janeiro State, Brazil (22'30'9.46"S, $44^{\circ} 42^{\prime} 44.29^{\prime \prime} \mathrm{WO}$ ), where occurred five human cases of BSF in 2006. The ticks were identified under a stereoscopic microscope and separated in pools by stages, species and sex. DNA extraction was carried out using QIAamp DNA Mini Kit (QIAGEN $\left.{ }^{\circledR}\right)$. The DNA was submitted to PCR amplification using 04 set of primers: $\operatorname{Rr} 190.70 p / R r 190.602 n$ (OmpA, 532bp), BG1-21/BG2-20 (OmpB, 650bp), Tz15/Tz16 (17 kDa protein-encoding gene, 246bp) and RpCS.877p/RpCS.1258n (gltA, 381bp). PCR products were separated by electrophoresis on $1 \%$ agarose gels and visualized under ultraviolet light with ethidium bromide. PCR products of the expected sizes were purified by QIAquick ${ }^{\circledR}$ and sequenced by $A B I$ PRISM ${ }^{\circledR}$. The generated nucleotide sequences were edited with using Bioedit $\Omega$ software and compared with the corresponding homologous sequences available through GenBank, using Discontiguous Mega Blast (http://www.ncbi.nlm.nih.gov). It was confirmed $R$. rickettsii by sequencing of the material (GenBank FJ356230). The molecular characterization of $R$. rickettsii in the tick $R$. sanguineus emphasizes the role of dogs as carriers of ticks from the environment to home. Moreover, this result suggests that there is a considerable chance for active participation of $R$. sanguineus as one of tick species in the transmission of $R$. ricketsii to human being in the Brazilian territory.
\end{abstract}

INDEX TERMS: Rhipicephalus sanguineus, Acari, Ixodidae, Rickettsia rickettsii, molecular analysis, Brazilian spotted fever.

\footnotetext{
${ }^{1}$ Received on July 18, 2008.

Accepted for publication on September 9, 2008.

2 Post-Graduate student, Curso de Pós-Graduação em Ciências Veterinárias, Universidade Federal Rural do Rio de Janeiro, Seropédica, RJ 23890-000, Brazil. E-mail: nathaliecunha@ hotmail.com

${ }^{3}$ Departamento de Epidemiologia e Saúde Pública, Instituto de Veterinária, Universidade Federal Rural do Rio de Janeiro (UFRRJ), Sero-
}

pédica, RJ 23890-000, Brazil. *Autor para correspondência: adivaldo@ufrri.br

${ }^{4}$ Laboratório de Hantaviroses e Rickettsioses, Instituto Oswaldo Cruz, FIOCruz, Pavilhão Hélio e Peggy Pereira, 1ํandar, Av. Brasil 4365, Manguinhos, Rio de Janeiro, RJ 21045-900, Brazil.

${ }^{5}$ Departamento de Parasitologia Animal, Instituto de Veterinária, UFRRJ, Seropédica, RJ. 
RESUMO.- [Primeira identificação de infecção natural por Rickettsia rickettsii no carrapato Rhipicephalus sanguineus no Rio de Janeiro.] A Febre Maculosa Brasileira (FMB) é uma zoonose causada por Rickettsia rickettsii e transmitida por carrapatos do gênero Amblyomma, mais freqüentemente pela espécie Amblyomma cajennense. Este trabalho tem como objetivo relatar a primeira detecção molecular de $R$. rickettsii em Rhipicephalus sanguineus naturalmente infectado no Rio de Janeiro, Brasil. Carrapatos foram coletados de cães, procedentes de uma região rural do município de Resende, estado do

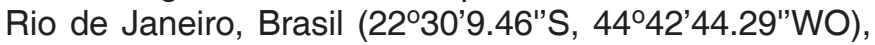
onde ocorreram cinco casos humanos de FMB em 2006. Todos os carrapatos foram identificados segundo chave dicotômica, utilizando-se lupa estereoscópica e separados de acordo com estágio, espécie e sexo. Para a extração de DNA utilizou-se o kit comercial QIAamp DNA (QIAGEN $囚$ ). O DNA foi submetido à técnica de PCR utilizando 04 conjuntos de iniciadores para a amplificação dos genes: Rr190.70p/Rr190.602n (OmpA, 532bp), BG121/BG2-20 (OmpB, 650bp), Tz15/Tz16 (17 kDa gene que codifica a proteína, 246bp) e RPCs .877p/RpCS.1258n ( $g / t A, 381 \mathrm{bp}$ ). Os produtos da PCR foram separados por eletroforese em gel agarose $1 \%$ corados com brometo de etídio e visualizados sob luz ultravioleta e, aqueles que apresentaram bandas amplificadas foram purificados utilizando-se o kit comercial QIAquick $®$ e seqüenciados pelo $A B I$ PRISM ${ }^{\circledR}$. As seqüências nucleotídicas foram geradas usando Bioedit $₫$, editado em software e comparados os correspondentes homólogos com as sequências disponíveis através GenBank, utilizando Discontiguous Mega Blast (http://www.ncbi.nlm.nih.gov). Confirmou-se R. rickettsii (GenBank FJ356230) no seqüenciamento de apenas um espécime, adulto de carrapato $R$. sanguineus. A caracterização molecular de $R$. rickettsii em exemplar de carrapato $R$. sanguineus confirma que esta espécie pode ter importante papel na transmissão de $R$. rickettsii para humanos no território brasileiro.

TERMOS DE INDEXAÇÃO: Rhipicephalus sanguineus, Acari, Ixodidae, Rickettsia rickettsii, Análise molecular, Febre maculosa brasileira.

\section{INTRODUCTION}

Brazilian spotted fever (BSF) is a life-threatening rickettsiosis caused by Rickettsia rickettsii that is transmitted to human beings by ticks of genus Amblyomma, more frequently, Amblyomma cajennense, a tick species primarily associated with horses (Dias \& Martins, 1939; Oliveira et al. 2000). Although other species of Rickettsia have been described in the Brazilian territory, as Rickettsia parkeri (Horta et al. 2004, Horta et al. 2007, Labruna et al. 2007) and Rickettsia felis (Cardoso et al. 2006, Oliveira et al. 2008), only $R$. rickettsii has been identified in BSF human cases.

Until recently, Dermancentor andersoni, D. variabilis in North American beside A. cajennense in South America were the only species of ticks associated with spotted fever rickettsioses on the American Continent (Parola et al. 2005). Nowadays, other species have been reported as A. triste (Venzal et al. 2008) in Uruguay and Rhipicephalus sanguineus in the USA (Demma et al. 2005, Wikswo et al. 2007).

Rhipicephalus sanguineus, commonly known as the brown dog tick, is a three-host tick that feeds primarily on dogs and occasionally on other hosts, including human beings (Walker et al. 2000). This tick species is the main vector and reservoir of Rickettsia conorii complex that cause Mediterranean spotted fever in Europe, Africa and Asia (Parola et al. 2005).

Although the role of $R$. sanguineus in the transmission cycle of a severe spotted fever rickettsiose to humans have been demonstrated since 1940's in Mexico (Bustamante et al. 1946, Bustamante et al. 1947), only in 2002, $R$. rickettsii was identified in $R$. sanguineus in the USA as important vector of the Rocky Mountain Spotted Fever (RMSF) in Eastern Arizona (Demma et al. 2005)

Burgdorfer et al. in 1975, registered the possibility of $R$. sanguineus involvement in the epidemiology of RMSF, reporting that ticks of this species collected in infected dogs with Rickettsia spp. were able to transmit and cause the disease, experimentally.

Recently in Brazil, human parasitism by $R$. sanguineus have been reported (Dantas-Torres et al. 2006, Louly et al. 2006). Till now, no data is published regarding the presence of vector-borne rickettsia in this specie of tick in a BSF endemic area.

On the other hand, recently $R$. sanguineus has been identified as reservoir of Rickettsia felis in Brazil (Cardoso et al. 2006, Oliveira et al. 2008), although previous studies had shown evidence of infected $R$. sanguineus in endemic areas in Brazilian states of Minas Gerais and Rio de Janeiro (Lemos et al. 1997a, Rozental et al. 2002)

The increasing number of cases of human parasitism by $R$. sanguineus ticks reported in the literature indicates that the interaction between human beings and $R$. sanguineus may be more common than it is recognized in the American continent.

Usually, $R$. sanguineus parasitizes dogs in urban areas, but sometimes they are found in rural farming areas (Soares et al. 2006, Labruna et al. 2001). In BSF endemic area, the conglomerations of $R$. sanguineus create a great risk to humans whose can be attacked by infected ticks in and around their houses. This study reports the first molecular detection of $R$. rickettsii in $R$. sanguineus ticks in Rio de Janeiro State, Brazil.

\section{MATERIALS AND METHODS}

The material here analyzed is part of an ongoing study that is been developing at Engenheiro Passos District (22030'165'S, $44^{\circ} 42^{\prime} 654^{\prime \prime}$ WO), located in the city of Resende, Rio de Janeiro State, Brazil where in May 2006 five BSF cases with two deaths were confirmed by serology. This area is situated in the western portion of the State in Paraíba do Sul middle river valley. The native vegetation, Atlantic Forest, has been replaced by 
degraded areas, characterized by the presence of livestock for milk production and current reforestation with Eucalyptus spp.

In June 2006, a study was conducted in this district, when ticks were collected from dogs and horses at or near site of confirmed cases of BSF. After identifying through a stereoscopic microscope using taxonomic key (Aragão \& Fonseca 1961, Barros-Battesti et al. 2006), the ticks were disinfected by immersion in $70 \%$ alcohol followed by washing in sterile water. Subsequently the ticks were separated in pools, by stage, species, sex and source.

DNA was extracted from ticks by freezing in liquid nitrogen and crushing with a sterile micropestle, ressuspended with 20il of sterile brain heart infusion (BHI) and stored at $-20^{\circ} \mathrm{C}$ until nucleic acid extraction. Total DNA was extracted from the pulverized ticks using QIAamp DNA Mini Kit (QIAGEN ${ }^{T M}$ ). DNA was divided in pools organized by locality, species and sex and were screened for the presence of Rickettsia DNA by polymerase chain reaction (PCR) using four set of primers: Rr190.70p/ Rr190.602n (OmpA) (Regnery et al. 1991), BG1-21/BG2-20 $(O m p B)$ (Eremeeva et al. 1994), Tz15/Tz16 (17 kDa protein enconding-gene.) (Tzianabos et al. 1989) and RpCS.877p/ RpCS.1258n ( $g / t A)$ (Roux et al. 1997). If a pool demonstrated an expected PCR product, DNA of each tick specimen that made part of that pool was individually tested.

PCR conditions consisted of an initial DNA denaturation and hot start at $95^{\circ} \mathrm{C}$ for $5 \mathrm{~min}$; followed by 40 consecutive cycles of $40 \mathrm{sec}$ denaturation at $95^{\circ} \mathrm{C}$, primer annealing at $55^{\circ} \mathrm{C}$ for 1 min, extension at $72^{\circ} \mathrm{C}$ for $1 \mathrm{~min} 10 \mathrm{sec}$, and a $7 \mathrm{~min}$ extension at $72^{\circ} \mathrm{C}$. For each reaction, $8 \mu \mathrm{l}$ of the DNA template from each individual tick sample were added to $2.5 \mu \mathrm{l}$ PCR buffer (10X Invitrogen ${ }^{\mathrm{TM}}$ ) buffer, $1.2 \mu \mathrm{l}$ of each primer $(20 \mathrm{mM}), 1.5 \mu \mathrm{l} \mathrm{MgCl}_{2}$ $(3 \mathrm{mM}), 0.25 \mu \mathrm{l}$ of dNTP mixture $(20 \mathrm{mM}), 0.25 \mu$ l Platinum Taq DNA Polymerase (5 U/ $\mu$ I Invitrogen ${ }^{\mathrm{TM}}$ ) and nuclease free water to a final volume of $25 \mu \mathrm{l}$. $5 \mu \mathrm{l}$ of DNA extracted from $R$. rickettsiiinfected Amblyomma cajennense ticks was used as positive control. PCR products were stained by ethidium bromide and visualized by electrophoresis in $1 \%$ agarose gel.

The PCR products of the expected amplicon size (BG-1-21/ BG2-20, OmpB, and RpCS.877p/RpCS.1258n, gltA) were purified by QIAquick ${ }^{\mathrm{TM}}$ and their forward and reverse nucleotide sequences were determined in a DNA sequencer analyzer (ABI Prism 3100 Genetic-Applied Biosystems/Perking Elmer, California, USA). Nucleotide sequence homologies, to determine similarities to other Rickettsia species, were established using NCBI BLASTn network service (http://www.ncbi.nlm.nih.gov/ BLAST).

\section{RESULTS AND DISCUSSION}

From the 1.445 ticks collected, Rhipicephalus sanguineus, Amblyomma cajennense, A. aureolatum, A. ovale, Dermacentor (Anocentor) nitens and Rhipicephalus (Boophilus) microplus, besides immature stages of Amblyomma sp. from animals, only 22 were submitted to molecular analysis until now. The result revealed PCR products for one specimen of $R$. sanguineus which showed amplicons to the four set of primers with $99 \%$ similarity to $R$. rickettsii (GenBank FJ356230p). The infected tick was identified as an engorged female, collected directly from a male dog, approximately one-year old, of Poodle breed, who lived freely in different environments in the rural property where the BSF cases occurred.
The occurrence of five confirmed cases of BSF in this region and the lack of $A$. cajennense infected by $R$. rickettsii, until now, is in agreement with the data showed by Demma et al. (2005) in which $R$. rickettsii was detected in $R$. sanguineus in an area in Arizona where the main vectors in United States, $D$. variabilis and $D$. andersoni were not identified.

More publications have showed evidence that the brown dog tick is the RMSF vector in some regions of the USA, where close human interaction with free-roaming community dogs heavily parasitized by these ticks is observed. Also, in California, where the role of $R$. sanguineus is unclear as a potential vector of this disease, $R$. rickettsii was detected in this tick, but some differences in genotypes were shown between the strains isolated from Arizona, demonstrating a significant genetic diversity in this species of the spotted fever group rickettsiae SFGR (Wikswo et al. 2007).

Although until now there is not strong evidence that $R$. sanguineus as the vector of BSF, previous studies have shown evidence of involvement of $R$. sanguineus in endemic regions in the states of Minas Gerais and Rio de Janeiro. Hemolymph samples of specimens collected from $R$. sanguineus were analyzed by Giemsa stain and immunofluorescence assay and microorganisms with similar morphology to (SFGR) were detected (Lemos et al. 1996, Lemos et al. 1997a, Rozental et al. 2002).

Currently, in Brazil, the main tick implicated in epidemiology of the BSF is $A$. cajennense, an ixodid with low specificity for the vertebrate host, its immature stages commonly are found parasiting human beings in rural areas or at least where primary hosts are found (Lemos et al. 1997b, Oliveira et al. 2000). A. aureolatum is another involved tick in the epidemiology of BSF, feeding on wild animals during it immature stages and parasitizing dogs during the adult stage. $R$. rickettsii was identified in this tick, collected from dogs at an endemic region of São Paulo state, suggesting be an important vector in Brazil (Pinter \& Labruna 2006).

Dogs from rural areas move freely in pastures, forests and stables around the houses, most of them being pets, mainly for children. Thus, the presence of these animals in homes is a risk factor for the occurrence of human cases, because they carry ticks from their natural environment into the house and/or to the neighboring areas.

Although this result is preliminary, the presence of $R$. sanguineus infected by $R$. rickettsi in a BSF endemic area confirms that this species may play a role in transmitting SFGR to human in Resende, state of the Rio de Janeiro, Brazil, an area where dogs, horses, cattle; domestic cats and their ticks have continuous contact with wild animals such as capybaras, marsupials and small rodents.

Acknowledgments- To CAPES, CNPq and FAPERJ for financial support and to the Municipal Secretary of Health of Resende.

\section{REFERENCES}

Aragão H. \& Fonseca F. 1961. Notas de ixodologia. VIII. Lista e chave para os representantes da fauna ixodológica brasileira. Mem. Inst. Oswaldo Cruz 59:115-129. 
Barros-Battesti D.M., Arzua M. \& Bechara G.H. 2006. Carrapatos de importância médico-veterinária da região neotropical: um guia ilustrado para identificação de espécies. $1^{\underline{a}}$ ed. Vox/ICTTD-3/Butantan, São Paulo. 223p.

Bustamante M.E., Varela G. \& Mariotte C.O. 1946. Estúdios de fiebre manchada en México: fiebre manchada en la Laguna. Revta Inst. Salubr. Enferm. Trop. 7:39-49.

Bustamante M.E. \& Varela G. 1947. Estúdios de fiebre manchada en México: papel del Rhipicephalus sanguineus en la transmission de la fiebre manchade en la Republica Mexicana. Revta Inst. Salubr. Enferm. Trop. 8:139-141.

Burfdorfer W., Sexton D.J., Gerloff R.K., Anacker R.L., Philip R.N. \& Thomas L.A. 1975. Rhipicephalus sanguineus: Vector of a new Spotted Fever Group Rickettsia in United States. Infect. Immun. 12(1):205-210.

Cardoso L.D., Freitas R.N., Mafra C.L., Neves C.V., Figueira F.C., Labruna M.B., Gennari S.M., Walker D.H. \& Galvão MA. 2006. Characterization of Rickettsia spp. circulating in a silent peri-urban focus for Brazilian spotted fever in Caratinga, Minas Gerais, Brazil. Cad. Saúde Publ. 22(3):495-501.

Dantas-Torres F., Figueredo L.A. \& Brandão-Filho S.P. 2006. Rhipicephalus sanguineus (Acari:Ixodidae), the brown dog tick, paraziting humans in Brazil. Revta Soc. Bras. Med. Trop. 39(1):64-67.

Demma L.J., Traeger M.D., Nicholson W.L., Paddock C.D., Blau D.M., Eremeeva M.E., Dasch G.A., Levin M.L., Singleton J., Zaki S.R., Cheek J.E., Swerdlow D.L. \& Mcquiston J.H. 2005. Rocky Mountain spotted fever from an unexpected tick vector in Arizona. N. Engl. J. Med. 353(6):587-594.

Dias E. \& Martins A.V. 1939. Spotted fever in Brazil: A summary. Am. J. Trop. Med. Hyg. 19:103-108.

Eremeeva M., Yu X. \& Raoult D. 1994. Differentiation among Spotted Fever Group Rickettsiae Species by Analysis of Restriction Fragment Length Polymorphism of PCR-Amplified DNA. J. Clin. Microbiol. 32(3):803-810.

Horta M.C., Labruna M.B., Sangioni L.A., Vianna M.C.B., Gennari S.M., Galvão M.A.M., Mafra C.L., Vidotto O., Schumaker T.T.S. \& Walker D.H. 2004. Prevalence of antibodies to spotted fever group rickettsiae in humans and domestic animals in a Brazilian Spotted Fever-endemic area in the state of São Paulo, Brazil: Serologic evidence for infection by Rickettsia rickettsii and another spotted fever group rickettsia. Am. J. Trop. Med. Hyg. 71(1):93-97.

Horta M.C., Labruna M.B., Pinter A., Linardi P.M. \& Schumaker T.T.S. 2007. Rickettsia infection in five areas of the state of São Paulo, Brazil. Mem. Inst. Oswaldo Cruz 102(7):793-801.

Labruna M.B., Souza S.L.P., Guimarães Jr, Pacheco R.C., Pinter A. \& Gennari S.M. 2001. Prevalência de carrapatos em cães rurais da região do norte do estado do Paraná. Arq. Bras. Med. Vet. Zoot. 53(5):553-556.

Labruna M.B., Horta M.C., Aguiar D.M., Cavalcante G.T., Pinter A., Gennari S.M. \& Camargo L.M.A. 2007. Prevalence of Rickettsia infection in dogs from the urban and rural areas of Monte Negro municipality, western Amazon, Brazil. Vector Borne Zoonotic Dis. 7(2):249-255.

Lemos E.R.S., Machado R.D., Coura J.R., Guimarães M.A.A. \& Chagasi N. 1996. Epidemiological aspects of the Brazilian Spotted Fever: Serological survey of dogs and horses in an endemic area in the state of São Paulo, Brazil. Revta Inst. Med. Trop. 38(6):427-430.
Lemos E.R.S., Machado R.D., Pires F.D.A., Machado S.L., Da Costa L.M.C. \& Coura J.R. 1997a. Rickettsiae-infected ticks in a endemic area of Spotted Fever in the State of Minas Gerais, Brazil. Mem. Inst. Oswaldo Cruz 92(4):477-481.

Lemos E.R.S., Machado R.D., Coura J.R., Guimarães M.A.A., SerraFreire N. M., Amorin M. \& Gazeta G.S. 1997b. Epidemiological aspects of the Brazilian spotted fever: Seasonal activity of ticks colleted in an endemic area in São Paulo, Brazil. Revta Soc. Bras. Med. Trop. 30(3):181-185.

Louly C.C.B., Fonseca I.N., Oliveira V.F. \& Borges L.M.F. 2006. Ocorrência de Rhipicephalus sanguineus em trabalhadores de clínicas veterinárias e canis, no município de Goiânia, GO. Ciênc. Anim. Bras. 7(1):103-106.

Oliveira P.R., Borges L.M.F., Lopes C.M.L. \& Leite R.C. 2000. Population dynamics of the free-living stages of Amblyomma cajennense (Fabricius, 1787) (Acari:Ixodidade) on pastures of Pedro Leopoldo, Minas Gerais State, Brazil. Vet. Parasitol. 92:295-301.

Oliveira K.A., Oliveira L.S., Dias C.C.A., Silva Jr A., Almeida M.R., Almada G., Bouyer D.H., Galvão M.A.M. \& Mafra C.L. 2008. Molecular identifi-cation of Rickettsia felis in ticks and fleas from an endemic area for Brazilian Spotted Fever. Mem. Inst. Oswaldo Cruz 103(2):191194.

Parola P., Paddock C.D. \& Raoult D. 2005. Tick-borne Rickettsioses around the world: Emerging diseases challenging old concepts. Clin. Microbiol. Rev. 18(4):719-756.

Pinter A. \& Labruna M.B. 2006. Isolation of Rickettsia rickettsii and Rickettsia bellii in cell culture from the tick Amblyomma aureolatum in Brazil. Ann. N.Y. Acad. Sci. 1078:523-529.

Roux V., Rydkina E., Eremeeva M. \& Raoult D. 1997. Citrate Synthase Gene Comparison, a new tool for phylogenetic analysis, and its application for the Rickettsiae. Int. J. Syst. Evol. Microbiol. 47(2):252261.

Regnery R.L., Spruill C.L. \& Plikaytis B.D. 1991. Genotypic identification of Rickettsiae and estimation of intraspecies sequence divergence for portions of two Rickettsial genes. J. Bacteriol. 173(5):1576-1589.

Rozental T., Bustamante M.C., Amorin M., Serra-Freire N.M. \& Lemos E.R.S. 2002. Evidence of spotted fever group Rickettsiae in state of Rio de Janeiro, Brazil. Revta Inst. Med. Trop. 44(3):155-158.

Soares A.O., Souza A.D., Feliciano E.A., Rodrigues A.F., D'Agosto M. \& Daemon E. 2006. Evaluation of ectoparasites and hemoparasites in dogs kept in apartments and houses with yards in the city of Juiz de Fora, Minas Gerais, Brazil. Revta Bras. Parasitol. Vet. 15(1):13-16.

Tzianabos T., Anderson B.E. \& McDade J.E. 1989. Detection of Rickettsia rickettsii DNA in Clinical Specimens by Using Polymerase Chain Reaction Technology. J. Clin. Microbiol. 27(12):2866-2868.

Venzal J.M., Estrada-Peña A., Castro O., De Souza C.G., Félix M.L., Navac S. \& Guglielmone A.A. 2008. Amblyomma triste Koch, 1844 (Acari: Ixodidae): Hosts and seasonality of the vector of Rickettsia parkeri in Uruguay. Vet. Parasitol. 155:104-109.

Walker J.B., Keirans J.E. \& Horak I.G. 2000. The Genus Rhipicephalus (Acari:Ixodidae): A guide to the brown ticks of the world. Cambridge University Press, Cambridge. 643p.

Wikswo M.E., Hu R., Metzger M.E. \& Eremeeva M.E. 2007. Detection of Rickettsia rickettsii and Bartonella henselae in Rhipicephalus sanguineus ticks from California. J. Med. Entomol. 44(1):158-162. 